\title{
Long-Run Human Development in Mexico: 1895-2010
}

\author{
Raymundo M. Campos-Vazquez, Cristóbal Domínguez Flores, \\ and Graciela Márquez
}

\section{Introduction}

In 1990, the United Nations Development Program (UNDP) proposed an alternative measure of development, the Human Development Index (HDI), a composite indicator of health, education, and income. Since then, researchers have increasingly used HDI estimates to explain the long-run evolution of standards of living in different countries and periods. In this chapter, we use the HDI to study long-run regional development in Mexico at subnational levels.

The literature using the HDI to measure well-being over time is extensive. Crafts $(1997,2002)$ calculated estimations for a set of 24 countries in the period 1870-1999, concluding that by the end of the twentieth century the gaps between Western Europe and developing regions were smaller than those present in the middle of the century. In a similar study, Prados de la Escosura (2010) concludes that the gap between developed and developing countries has narrowed over time, although the degree of convergence has slowed since 1970. Astorga et al. (2005) construct an HDI series for Latin American countries and conclude that the region experienced the largest gains in living standards in the middle decades of the twentieth century. Bértola et al. (2010) compute an inequality-adjusted historical human development index for Argentina, Brazil, and Uruguay in the twentieth century. These authors compare the results to developed countries (France, Germany, the UK, and the USA) and find divergence in Argentina from the early decades of the twentieth century, while Uruguay began the same pattern in the 1950s.

This chapter has benefitted by comments from the participants of the seminar "Latin American Inequality in the Long Run” Buenos Aires, 3-5 December, 2014. We also want to thank the insightful suggestions by Jeff Williamson and Luis Bértola. All remaining errors are our responsibility.

R.M. Campos-Vazquez $(\bowtie) \bullet$ C.D. Flores $\bullet$ G. Márquez

El Colegio de Mexico, Camino al Ajusco 20, Mexico City 10740, Mexico

(C) The Author(s) 2017

L. Bértola, J. Williamson (eds.), Has Latin American Inequality

Changed Direction?, DOI 10.1007/978-3-319-44621-9_5 
Brazil was steadily catching up until 1980, when it finally began to diverge from the core countries. ${ }^{1}$ It is worth noting that these papers compare the indices across countries over time, and that little research exists on well-being within countries using HDI estimates.

In Mexico, the study of living standards has been developed using different approaches, considering income and non-income components. Bortz and Águila (2006) analyze real wages from the Porfiriato (1876-1911) to the early twenty-first century and conclude that the largest increases took place between 1952 and 1970, while the economic crises of the 1980s and 1990s caused a drastic reduction in real wages. López-Alonso (2007, 2012) uses anthropometric measures (adult heights) drawn from military and passport data. These studies identify a deterioration in the standard of living of the laboring classes over time, in contrast to an increase for the elite and upper middle classes. ${ }^{2}$ Recently, Challú and Gómez (2015) found that real wages of non-skilled workers in Mexico City exhibited a secular decline since the mid-eighteenth century and only partially recovered from the late 1860s to 1930 . Esquivel (1999) finds convergence in GDP per capita at state level from 1940 to 1960, and a relative constant dispersion thereafter.

Campos-Vazquez and Velez (2012) calculate a human development index to study human development at the state level from 1895 to 1910 . Their results show important improvements in the 1895-1910 period, but these improvements are not distributed proportionately among states. Márquez (2012) applies the methodology developed by these two authors to study state-level human development in 1930 . Her study shows an improvement in human development in comparison to the 1895-1910 period. Interestingly, the regional development pattern found by Campos-Vazquez and Velez is also found in this study, suggesting an important structural difference in development between the northern and southern regions of the country.

In this chapter, we analyze the development of Mexico over the long run (1895-2010) using an HDI measurement at the subnational level to facilitate a comparison across regions. Our methodology provides a consistent standard of living measure based upon proxy variables to those generally used for recent periods. ${ }^{3}$ The chapter is organized as follows. Section 2 discusses the historical background

\footnotetext{
${ }^{1}$ These results are at odds with those of other scholars, which show a general pattern of "convergence in the central decades of the century and relatively stable situation afterwards" (Bértola et al. 2010, p. 219).

${ }^{2}$ See, for example: "The evolution of the biological standards of living of the laboring classes, measured as the evolution of stature, does not follow trends in Mexico's overall economic performance, while that of the elite and upper middle classes does. The trends in stature suggest that the living standards of the laboring classes gradually deteriorated from the 1870s" (López-Alonso 2007, p. 102).

${ }^{3}$ Esquivel et al. (2003) analyze convergence of HDIs since 1950. García-Verdú (2005) analyzes human development at the state level for 2000. Permanyer (2013) calculates HDIs at the municipal level in 1990, 2000, and 2010. Recently, Aguilar Retureta (2015) documents relative participation of GDP per capita across states in Mexico. He finds, similar to our results, that inequality increases up to 1940 and then steadily declines.
} 
on Mexico's history since 1895 and the literature that have applied human development concepts to the Mexican experience. Section 3 presents the methodology and data sources used in our estimates. Following, in Sect. 4, we offer main results of our study. Section 5 summarizes our findings and offers some conclusions.

\section{Historical Background}

Mexico experienced significant economic changes along the twentieth century that enabled the country to overcome past obstacles to growth while facing new challenges to improve the well-being of the population. In the last quarter of the nineteenth century Mexico grew at a sustained rate, in sharp contrast with the performance of the first 50 years after independence. Indeed, from 1821 to around 1870, Mexico stagnated, with episodes of weak recoveries and decline. ${ }^{4}$ Although economic historians have debated the pace of the slow secular growth, there is consensus on the recovery from the 1870s to the outbreak of the Mexican Revolution in 1910. During the Porfiriato (1876-1911) railroad construction, foreign demand for mineral and agricultural products, and enactment of regulations to secure property rights all contributed to the modernization of crucial sectors of the economy.

By 1910, Mexico was a wealthier economy than 30 years earlier. Ports, major cities, mines, and industrial centers were all connected by railroads, larger banks had branches throughout the country, and internal taxes increased their share of total federal revenue. However, economic growth did not reach all regions of the country with the same intensity. Mining districts, industrial centers, and export-oriented agriculture became engines of growth, but they coexisted with low-productivity agriculture and isolated regions with few connections to international markets.

The Mexican Revolution had uneven consequences on the economy. The areas disputed by different leaders were hit hard by the civil war. But even in this situation economic production did not come completely to a halt: the production of foodstuffs continued, in many instances promoted by revolutionary leaders; oil fields increased their output in response to growing international demand; and the geographic isolation of the Yucatan peninsula allowed henequen haciendas to supply the American market. By the end of the armed phase of the revolution a new institutional arrangement, centered in the 1917 Constitution, set in motion a land reform program and changes in labor legislation. Also, the government acquired a more interventionist stance in the economy which shaped social and economic policy in the decades to follow.

The economic disturbances caused by the revolutionary upheaval were neither generalized nor permanent, but their consequences differed across regions and sectors. In the 1920s mineral and agricultural exports continued to drive economic growth.

${ }^{4}$ For a discussion of the growth trajectory since independence see Cárdenas (2003), Coatsworth (1978), Márquez (2013), and Sánchez Santiró (2009). 
New investment in manufacturing also contributed to the recovery of the economy while the banking system slowly regained its basic functions. In contrast, Mexico was in arrears, without access to foreign loans, and in difficult negotiations with its creditors. Private investors were more reluctant to channel resources to agriculture than to manufacturing and mining, in part because of uncertainty created by the land reform program implemented by postrevolutionary governments.

Also, certain policies changed radically in the new institutional environment. In restructuring the economy the federal government introduced direct taxation (income tax), created the central bank, and established development banks in support of agriculture and industry. The provision of education and health services became priorities for the federal and state governments. Vaccination campaigns, eradication of epidemics, and sewage projects gained support among public officials. The School of Public Health was founded in 1922, and national health campaigns emerged as part of the social policy of the 1920s. The establishment of the Ministry of Public Education (Secretaría de Educación Pública, SEP) included an ambitious literacy program and the establishment of rural schools, and the federal government increased its efforts to centralize education policy (Fierro et al. 2009).

By 1926, as foreign demand for Mexican products tapered off, an economic slowdown was evident, and the international crisis in 1929 aggravated an already delicate situation. A sharp decline in international prices and the collapse of external markets constrained Mexico's capacity to grow, and that of other countries in Latin America, until 1932. However, the resumption of growth in that year initiated a 50-year period of sustained economic expansion. The closure of foreign markets during the 1930s opened up favorable conditions for the production of consumer and intermediate goods, while the early recovery from the external shock guaranteed domestic demand. Under the Lázaro Cárdenas administration (1936-1940) social expenditure soared and land reform policy broadened. Although the pace of land distribution leveled off subsequently, the government performed an active role in the economy through public investment in infrastructure, provision of cheap energy, and subsidies of raw materials and intermediate goods. Industrialization reached its stride with protectionist policies, fiscal incentives, and restrictions on foreign capital. The 1950 s and early 1960s were characterized by low inflation, exchange rate stability, and average GDP yearly growth of more than $6 \%$. In addition to high growth rates and price stability the expansion of health services and public education all contributed to improvements in social welfare and a betterment of income distribution.

In the mid-1960s the so-called Mexican miracle showed the first signs of profound economic woes. A growing trade and public deficits, lack of competitiveness of the industrial sector, and falling productivity in agriculture reveal serious obstacles to sustain sound economic growth in the years to come. By the early 1970s, structural problems mounted. The government chose fiscal expansion as the means to deal with its economic difficulties, resulting in rising inflation, an exploding public deficit, and an external deficit that required increased foreign borrowing. Inflation and devaluation ensued. The discovery of rich oil deposits coupled with the rise in international oil prices changed the prospects for the Mexican economy at the end of the 1970s. 
Growth resumed without resolution of the structural problems. Foreign debt was initially devoted to building an oil export platform, but the overvaluation of the peso and the deindustrialization associated with the so-called Dutch disease soon forced the government to increase borrowing. In 1981, international oil prices declined and interest rates rose, limiting the possibility of foreign financing. A year later, neither the devaluation of the peso nor the exchange rate controls had proven sufficient and, in consequence, the government declared a 3-month moratorium on the external debt and the nationalization of private banks. Mexico shared with other Latin American countries the problem of not only overindebtedness, but also an industrial base dependent on imported inputs, overprotected domestic markets, and a lack of international competitiveness. Severe cuts in public investment, a reduction in bureaucracy, elimination of subsidies, and price controls failed to recover a path of sustained growth or control inflation. Overall, in the 1980s, growth was mediocre. ${ }^{5}$

In the midst of the external debt crisis Mexico took a risky gamble. Instead of tightening the protectionist barriers, President Miguel de la Madrid (1992-1998) decided to liberalize the economy. A first step towards this goal was to join the General Agreement on Tariffs and Trade (GATT), which required the elimination of quantitative import controls and the lowering of import duties. To avoid future policy reversals, President Carlos Salinas (1988-1994) promoted the North American Free Trade Agreement (NAFTA) with the USA and Canada. Opening up the economy had initially aimed at increasing the flow of foreign direct investment; yet actual capital flows to the Mexican economy fell short of expectations (both in the mid-1980s and in the early 1990s). However, liberalization became the cornerstone for a new model of growth, one that placed significant emphasis on exports as the driving force of the economy. Completing the shift to this model also required a change in the role of the government. The sale of public enterprises at the start of the foreign debt crisis began as a measure to reduce the public deficit, but later became one of the pillars supporting a shift to a market-oriented economy. ${ }^{6}$

The changes in the Mexican economy were so profound that some authors did not hesitate to describe them as a revolution. ${ }^{7}$ In addition to NAFTA, President Salinas (1988-1994) launched ambitious economic reforms including the landholding regime of the ejido to allow peasants to sell their plots, recasting the Bank of Mexico as an autonomous agency with a mandate to control inflation, passage of an antitrust law with establishment of a Federal Competition Commission, as well as privatization of banks, steel plants, the telephone company, television stations, and railroads, among other industries. However, these reforms were insufficient to recover high rates of growth needed to compensate for the "lost decade" of the $1980 \mathrm{~s} .^{8}$

\footnotetext{
${ }^{5}$ See Moreno-Brid and Ros (2009), Chap. 6, and Cárdenas (2010).

${ }^{6}$ Haber et al. (2008).

7 "If by 'revolution' we mean a dramatic change in the institutions that organize economic, political, and social life, then Mexico has undoubtedly been in the midst of a revolution since the early 1980s" (ibid., p. 1).

${ }^{8}$ Márquez and Meyer (2010).
} 
A currency crisis in late 1994 led the Mexican economy to a severe drop in output equivalent only to that of the 1930s. Despite a quick recovery, the effects on well-being were not easy to overcome. After a decade of mediocre growth in the 1980s, the new crisis deepened the vulnerabilities of the middle- and low-income strata of society. In the first decade of this century, social programs coupled with macroeconomic stability had ameliorated the effects of years of slow growth. However, the international financial turmoil of 2008 caused another large dip in the growth trajectory, losing the gains in well-being brought about by social programs.

Over the course of more than a century the Mexican economy experienced a profound transformation. At the end of the nineteenth century the majority of the population lived and worked in rural areas, the railroad grid was crucial to the transportation of mineral and agricultural exports, and education and health services were limited and provided mostly in urban areas. In 2010, most Mexicans lived in cities, most children had access to primary education, and the country's export basket combined raw materials and manufactures. Between these two moments of Mexican history, the country changed its patterns of growth from a primarily export model to an import substitution industrialization strategy, and finally to a marketoriented economy. How did well-being develop over time? Can we observe any continuity in regional patterns? These questions are addressed in the following sections, where we present the results of estimates of human development indexes from 1895 to 2010 .

\section{Methodology and Data}

In its original version the HDI was calculated as a simple average of the health, education, and income indexes. The health index is related to life expectancy, the education index to enrollment and literacy rates, and the income index to per capita income. Since 2010, the HDI has been calculated as a geometric mean of its components:

$$
\text { HDI }=\text { Health }^{1 / 3} \cdot \text { Education }^{1 / 3} \cdot \text { Income }^{1 / 3}
$$

This new methodology has several advantages. First, it avoids the perfect substitutability problem of the simple average aggregation. In other words, if one subindex gains at the expense of another, the previous formula would not reflect a changed HDI, while the new formula does. Second, as a consequence of imperfect substitutability, uneven progress can be accounted for as a negative effect on the overall index. Finally, the maxima chosen in the normalization of each subindex are irrelevant (Klugman et al. 2011). ${ }^{9}$

\footnotetext{
${ }^{9}$ We calculate the geometric mean in order to apply the current HDI methodology to our index. Using the previous methodology, mean with equal weights to each index, does not change the main conclusions of this chapter.
} 
In order to construct the HDI in Eq. (1), we use proxy variables for each subindex following Campos-Vazquez and Velez (2012) and Ian Morris (2013). First, the calculation of the education index takes into account the variables and weights proposed by UNDP (2010). The only difference is that we restrict the upper bound of the age range of literacy rates for individuals to 12 years instead of 24 years as specified by UNDP (2010). We thus calculate the education index as a weighted average of literacy rates (LR) for individuals older than 15 years of age and enrollment rates (ER) for individuals aged 6-12 years such that

$$
\text { Education }=\frac{2}{3} \mathrm{LR}+\frac{1}{3} \mathrm{ER} \text {. }
$$

Second, instead of using life expectancy, we use the number of physicians for each 10,000 inhabitants. Our proxy variable is a good measure of the health standard if we considered the effect of access to medical services in overall health. There is a large range of studies documenting the importance of the number of physicians on the health status of the population. For example, Shi $(1992,1994)$ has shown that US states where the number of physicians per capita is higher have better health outcomes. This is in line with results of Robst and Graham (1997, 2004) also for the USA. They show a positive influence of the number of physicians on the health status of the population. Moreover, they find a higher correlation in rural areas across the USA than urban areas. Vogel and Ackermann (1998) have shown a positive relation between a higher supply of physicians and life expectancy. Finally, Pièrard (2009) shows that a higher supply of general practitioners in Canada is correlated with better health outcomes, including self-reported measures of health status.

Our proxy variable for life expectancy, the number of physicians per 10,000 inhabitants, is a good measure of the health standard if we consider the effect of access to medical services on overall health. ${ }^{10}$ To construct this subindex, we use the number of physicians (NP) per 10,000 inhabitants relative to 35, which was the corresponding figure for 2001 in Switzerland, the country in Europe with the highest life expectancy. The health index is thus constructed as

$$
\text { Health }=\frac{N P}{35}
$$

\footnotetext{
${ }^{10}$ There is a large range of studies documenting the importance of the number of physicians to the health status of the population. For example, Shi $(1992,1994)$ and Robst and Graham $(1997,2004)$ show a positive influence of the number of physicians on the health status of the US population; the latter, moreover, find a higher correlation in rural areas than in urban ones. Vogel and Ackermann (1998) show a positive relation between number of physicians and life expectancy. Finally, Piérard (2009) shows that a greater supply of general practitioners in Canada is correlated with better health outcomes, including self-reported measures of health status. In the data section, we provide the sample correlations of number of physicians and life expectancy for recent years.
} 
Third, instead of using income, we use urbanization rates. There is a long tradition in economic history of using urbanization rate as a proxy for economic development. Paul Bairoch $(1975,1988)$ presents a compelling argument that urbanization is correlated with economic development for both developed and developing regions. A book by Komlos (1994) reaches a similar conclusion. Moomaw and Shatter (1996) formally test the previous argument using a panel data of countries and find that indeed urbanization increases with GDP per capita. More recently, Acemoglu et al. (2002) convincingly argue that population density and urbanization are a good proxy for economic development. For a sample of Latin American countries, Astorga et al. (2005) find that urbanization is positively correlated with living standards in the period 1900-2000. In the study of how culture affects economic development in Europe, Tabellini (2010) argues that urbanization rates are a good proxy for economic development. Nunn and Qian (2011) argue that the introduction of potatoes to the Old World improved nutrition and agricultural productivity which lead to higher urbanization rates and higher economic development. Finally, Cali and Menon (2013) find that urbanization causes rural poverty to decline through increased demand for agricultural products in the case of Indian districts. Furthermore, disaggregated urbanization data for developing countries is generally more easy to find whereas GDP per capita estimates were often inexistent or lacked precision as the analysis moved back in time. In so doing we attempt to provide a basis of comparison with cases or historical periods with little information. Nevertheless, we should keep in mind that urbanization is a good proxy for income in the long run, but urbanization may not follow the same short-run fluctuation as income. The positive results of the consistency test (see next section) support our choice of urbanization as a proxy for income in the long run. As urbanization is already a number between zero and one, we do not need to transform it into an index; we simply introduce it in Eq. (1) as proxy of the subindex income.

Table 1 summarizes the definitions of the subindices explained above. In sum, as a proxy for per capita income we use urbanization rate. For health, we use the number of physicians per 10,000 inhabitants. For education, we can closely mimic the official definition in the HDI calculation.

Table 1 Components of HDI as in UNDP (2010) and variables used in the study

\begin{tabular}{|c|c|c|}
\hline Subindex & UNDP (2010) & Our estimation \\
\hline Income & GDP per capita & Urbanization rate \\
\hline \multirow[t]{2}{*}{ Education } & $\begin{array}{l}\text { Enrollment rate of individuals } \\
\text { older than } 15 \text { years }\end{array}$ & $\begin{array}{l}\text { Enrollment rate of individuals older than } 15 \\
\text { years }\end{array}$ \\
\hline & $\begin{array}{l}\text { Literacy rate in individuals aged } \\
6-24 \text { years }\end{array}$ & Literacy rate in individuals aged 6-12 years \\
\hline Health & Life expectancy rate & $\begin{array}{l}\text { Physicians per } 10,000 \text { inhabitants relative to } \\
35 \text { (physicians in Switzerland in 2001) }\end{array}$ \\
\hline
\end{tabular}




\subsection{Construction of the Education Index}

Education variables are the best measured variables in our dataset. Literacy rates for the population aged 15 years and older are available at the state level for every year of interest in Estadísticas Históricas de México (INEGI 2009) and Censo General de Población y Vivienda (INEGI 2010a, b). Enrollment rates are defined as the share of population aged 6-12 years who are enrolled in school. From 1920 to 2010, enrollment rates are calculated using data available in the population censuses. Rates from 1900 to 1910 are calculated using data from Estadísticas económicas del Porfiriato (Colegio de México 1964) and Estadísticas sociales del Porfiriato (Secretaría de Economía 1956). Only the enrollment rates from 1895 have to be estimated. ${ }^{11}$ Both literacy rates and enrollment rates are also calculated using microdata from the Population Censuses from 1990 onwards provided by IPUMS (Minnesota Population Center 2011).

It would be preferable to use enrollment rates for the population aged 6-24 years, but there is not enough data available for 1920, 1930, and 1940 to calculate them. Correlations between enrollment rates for persons aged 6-12 years and those aged 6-24 years for 1950,1970 , and 1990 are $0.98,0.96$, and 0.81 , respectively. ${ }^{12}$

\subsection{Construction of the Health Index}

The number of physicians per 10,000 inhabitants is the best proxy variable that can be used for the whole period of study. Although the origin of the data is varied, the number of physicians per state is available for most of the years under study. The number of doctors at the state level is available in Estadísticas Sociales del Porfiriato (Secretaría de Economía 1956) for the period 1895-1910, in Mendizábal (1947) for 1930, in Huerta Maldonado (1960) for the mid-1950s, in N. Myers (1971) for 1960, and in Frenk et al. (1995) for 1970 and 1990. Numbers for 1980

\footnotetext{
${ }^{11}$ State-level enrollment rates for 1895 were estimated by pooling ordinary least squares using data from 1900 to 1910:

$$
\begin{aligned}
& \text { enroll }_{i, t}=11.6+0.19 \text { Dens }_{i, t}+0.368 \text { Prof }_{i, t}-7.31 \text { Dummy }^{2} \\
& \text { se : }(2.19)(0.15)(0.16)(1.37) \quad R^{2}=0.65
\end{aligned}
$$

where enroll $\mathrm{i}_{\mathrm{i}, \mathrm{t}}$ is the enrollment rate in percentage points for state $i$ at year $t$, Dens $_{\mathrm{i}, \mathrm{t}}$ is the population density per square kilometer, Prof $\mathrm{i}_{\mathrm{i}, \mathrm{t}}$ is the number of teachers per 10,000 persons, and Dummy is a binary variable that takes value 1 if the enrollment rate is less than $10 \%$ for either of the 2 years and zero otherwise.

${ }^{12}$ The Spearman correlations for 1950,1970 , and 1990 are $0.99,0.96$, and 0.74 , respectively. The hypothesis of independence between both variables for every year is rejected at any typically used significance level. The correlation between the variables is clearly reduced from 2000 onwards, when enrollment rates in elementary school reached levels closer to $90 \%$.
} 
were interpolated from the latter source, and yearbooks published by the National Statistical Institute (INEGI) provided the observations from 2000 to 2010 in a more homogenous manner. ${ }^{13}$

There is no data available for the number of physicians at the state level for 1920 and 1940, so we impute these values using econometric methods. Trends of physician concentration were clearly different before and after 1930, so two estimations are needed. The number of physicians for 1920 is estimated using data from 1895, 1900, 1910, and 1930, and the number for 1940 using data from 1950, 1960, and $1970 .{ }^{14}$

Statistical evidence also supports the proposition that the number of physicians is a good proxy variable for the health dimension. The correlations between the number of physicians and life expectancy for 1950, 1990, and 2000 are $0.78,0.61$, and 0.54 , which implies a strong positive relation. ${ }^{15}$ Furthermore, we expect that the relationship between physicians and life expectancy should be stronger for earlier years of the study, given that transportation costs were higher.

\footnotetext{
${ }^{13}$ Specifically, we are using data from the Anuario de Estadísticas por Entidad Federativa (INEGI 2004, 2009, 2011).

${ }^{14}$ We estimated the number of physicians for 1920 and 1940 using different datasets, pooling ordinary least squares. For 1920, we restricted data to 1895, 1900, 1910, and 1930:

$$
\begin{aligned}
& \text { phys }_{i, t}=6.78+0.0028 \text { Dens }_{i, t}+0.034 \mathrm{Mort}_{i, t}-4.89 \mathrm{reg} 1 \\
& -4.59 \mathrm{reg} 2-6.54 \mathrm{reg} 3-6.88 \mathrm{reg} 4-5.92 \mathrm{reg} 5 \\
& \text { se : }(1.19)(0.0012)(0.016)(0.95) \\
& (1.13)(0.80)(0.74)(0.87) \quad R^{2}=0.70
\end{aligned}
$$
}

For 1940, we restricted data to 1950,1960 , and 1970:

$$
\begin{aligned}
& \text { phys }_{i, t}=22.2-0.0007 \mathrm{Dens}_{i, t}-0.158 \text { Mort }_{i, t}-14.6 \mathrm{reg} 1 \\
& -15.1 \mathrm{reg} 2-16.8 \mathrm{reg} 3-16.4 \mathrm{reg} 4-16.9 \mathrm{reg} 5 \\
& \text { se }:(4.05)(0.0018)(0.054)(3.93) \\
& (3.93)(3.81)(3.73)(3.87) \quad R^{2}=0.71
\end{aligned}
$$

where phys $\mathrm{i}_{\mathrm{i}, \mathrm{t}}$ is the number of physicians for state $i$ at year $t$, Dens $\mathrm{s}_{\mathrm{i}, \mathrm{t}}$ is the population density per square kilometer, Mort $\mathrm{i}_{\mathrm{i}, \mathrm{t}}$ is the mortality rate, and reg1-reg5 are dummy variables per region as previously defined. We estimated different interpolation models but we obtained qualitatively similar results.

${ }^{15}$ The Spearman correlations for 1950, 1990, and 2000 are 0.69, 0.67, and 0.53, respectively. The hypothesis of independence between both variables for every year is rejected at any typically used significance level. 


\subsection{Construction of the Income Index}

The urbanization rate is defined as the share of the population living in communities with more than 2500 inhabitants. ${ }^{16}$ We need to rely on an estimation of the urbanization rate only for the year 1895. ${ }^{17}$ Data available in Estadísticas económicas del Porfiriato (El Colegio de México 1964) is used to calculate urbanization rates for 1900 and 1910, and population census data is used for the period 1920-2010. Statistical evidence also supports that urbanization is a good proxy variable for the income dimension; correlations between urbanization and per capita income for 1970,1990 , and 2000 are $0.76,0.78$, and 0.84 , respectively. ${ }^{18}$

\section{Results}

\subsection{Consistency}

Table 2 includes the calculations for each subindex in the period 1895-2010 as well as the value of the historical HDI using Eq. (1). Before analyzing these results we need to establish their relation to existing estimates using the definitions and variables specified by UNDP (2010). We performed a consistency test comparing our estimates with existing HDI estimates for the 1950-2000 period. We obtained 1950-2010 values of the HDI from the results of Gerardo Esquivel et al. (2003), and PNUD (2003, 2012). We contrasted these values (referred as HDI* in Fig. 1) with our measure of HDI. The result is shown as a scatterplot in Fig. 1.

Figure 1 shows HDI on the $x$-axis and HDI* on the $y$-axis; each dot represents a state in the period 1950-2010. We also included a regression line for reference. The two series are highly collinear. Indeed, the correlation coefficient is equal to 0.88 (the Spearman coefficient, 0.87). The slope parameter in the regression line is 0.61 and is significant at the $1 \%$ level. Because the HDI is highly related to HDI* we are

\footnotetext{
${ }^{16}$ It might be argued that this threshold is too low. However, homogenous data using a different threshold is not available. Moreover, it is not clear that we should use a higher threshold (for example 15,000) for recent periods.

${ }^{17}$ We use the same estimation as Campos-Vazquez and Velez (2012), p. 616. The data was obtained by pooling ordinary least squares:

$$
\begin{aligned}
& \mathrm{Urb}_{i, t}=31.77+0.094 \text { Dens }_{i, t}+1.189 \mathrm{NP}_{i, t}-8.261 \text { Dummy } \\
& \text { se }:(1.649)(0.011)(0.512)(0.879) R^{2}=0.884
\end{aligned}
$$

${ }^{18}$ The Spearman correlations for 1970, 1990, and 2000 are $0.73,0.73$, and 0.81 , respectively. The hypothesis of independence between both variables for every year is rejected at any of the typically used significance levels.
} 
Table 2 National HDI and components

\begin{tabular}{l|l|l|l|l}
\hline & & Subindexes & \\
\cline { 3 - 5 } Year & Human development index & Urbanization & Education & Health \\
\hline 1895 & 0.133 & 0.277 & 0.164 & 0.052 \\
\hline 1900 & 0.151 & 0.283 & 0.220 & 0.055 \\
\hline 1910 & 0.155 & 0.285 & 0.230 & 0.057 \\
\hline 1920 & 0.174 & 0.309 & 0.290 & 0.059 \\
\hline 1930 & 0.195 & 0.335 & 0.371 & 0.060 \\
\hline 1940 & 0.231 & 0.351 & 0.379 & 0.093 \\
\hline 1950 & 0.317 & 0.426 & 0.504 & 0.149 \\
\hline 1960 & 0.364 & 0.507 & 0.600 & 0.159 \\
\hline 1970 & 0.435 & 0.587 & 0.696 & 0.202 \\
\hline 1980 & 0.533 & 0.663 & 0.784 & 0.292 \\
\hline 1990 & 0.605 & 0.713 & 0.866 & 0.358 \\
\hline 1995 & 0.629 & 0.735 & 0.906 & 0.374 \\
\hline 2000 & 0.654 & 0.746 & 0.909 & 0.412 \\
\hline 2005 & 0.673 & 0.765 & 0.926 & 0.431 \\
\hline 2010 & 0.703 & 0.768 & 0.932 & 0.485 \\
\hline
\end{tabular}

Source: Own calculations

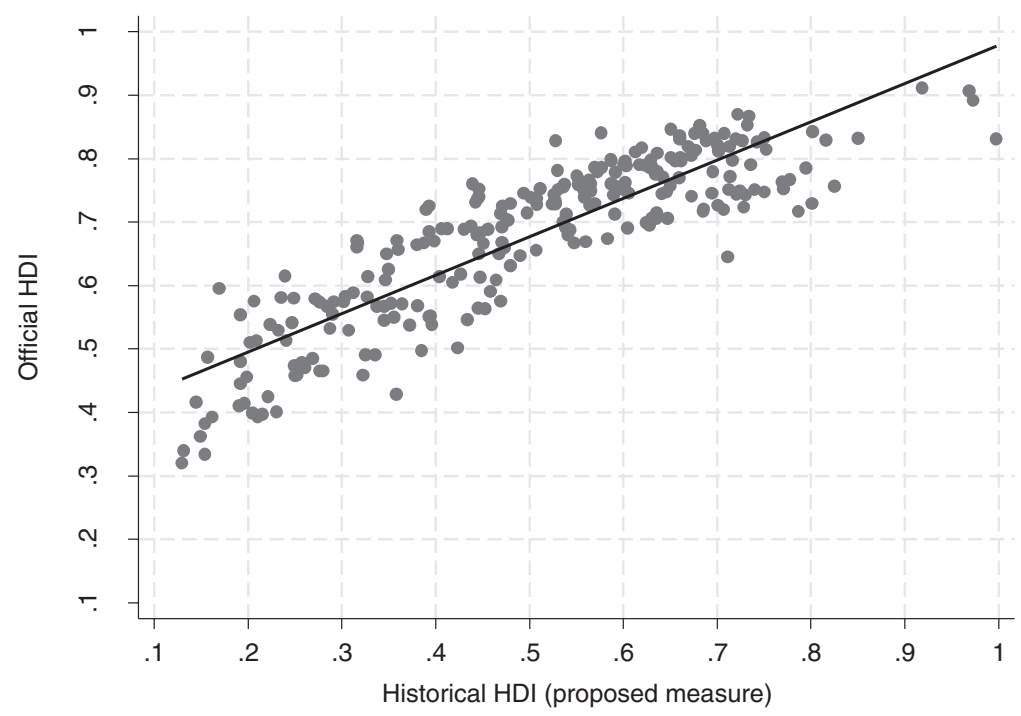

Fig. 1 Relationship between official HDI and proposed historical HDI: 1950-2010. Sources: Historical HDI obtained from results calculated by the authors. Official HDI from 1950 to 1995 obtained from Esquivel et al. (2003), 2000 from PNUD (2003), and 2010 from PNUD (2012). Notes: Calculated by the authors. Includes all HDI and HDI* values of each state for the period 1950-2010, including 1995 and 2005. There is a total of 256 observations. The correlation coefficient is equal to 0.878 and the Spearman correlation is equal to 0.868 and significant at the $1 \%$ level. The regression obtained is equal to $H D I=0.37+0.61$ ProposedHDI, with a $t$-statistic on the coefficient of HDI equal to 29.3 and $R^{2}$ of 0.77 
HDI: Mean, Minimum, and Maximum

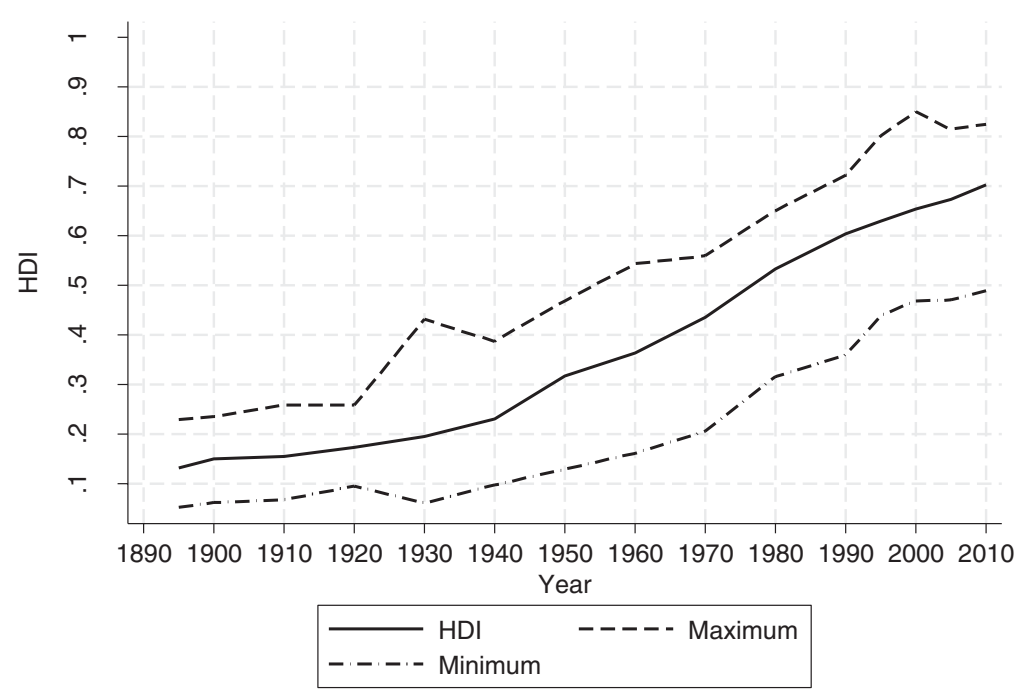

Fig. 2 HDI, 1895-2010. HDI mean, minimum, and maximum. Notes: Calculations by the authors. The figure includes the evolution of HDI for the full sample over time using an average weighted for the population in each state and period. The maximum refers to the second maximum, as the first maximum is always Mexico City

able to draw inferences on long-run human development for Mexico at the national and the regional levels.

\subsubsection{Main Results at National Level}

Figure 2 shows the evolution of the national-level HDI, calculated as the average of state-level HDI weighted by population. Human development shows an improving trend over the twentieth century, a result comparable to the rise in heights found by Moramay Lopez-Alonso and Roberto Velez in this volume. Furthermore, for the period as a whole, Mexico shows an average acceleration rate of $1.45 \%,{ }^{19}$ very close to the figure of $1.4 \%$ reported by Prados de la Escosura (2010) for a sample of 88 countries in the period 1870-2005, suggesting that Mexico's experience in human development is similar to that of the rest of the world.

The long-term evolution of the HDI allows us to differentiate three periods: one before 1940 with moderate increases; a second from 1940 to 1980 , with major gains in the standard of living; and a third beginning in 1980 with indices of wellbeing still increasing but at a slower rate. These three periods are clearly related to

${ }^{19}$ We thank Luis Bértola for pointing out that this is an acceleration rate. 
the historical processes described in the historical review. First, from 1895 to 1940, encompassing the late Porfiriato, the revolution, and the postrevolutionary period, Mexico experienced low-to-moderate improvements in standards of living resulting from uneven economic growth and erratic social policies. Second, from 1940 to 1980 there are important gains in human development. As discussed in Sect. 2, the manufacturing sector became the engine of growth, and the country registered significant increases in public and private investment as well as the establishment of social security in 1943, and the expansion of universal primary education, hospitals, and public health campaigns. ${ }^{20}$ Third, since 1980, improvements in human development have slowed down in light of the advancements of those achieved in the previous four decades. ${ }^{21}$ The acceleration rate of the HDI from 1980 to 2010 was reduced due to sluggish economic performance and the serious macroeconomic shocks of the foreign debt crisis of the 1980s, the currency crisis of 1995 , and the recession of 2008-2009. Social spending has ameliorated the effects on well-being, but half of the Mexican population still lives below the poverty line. In sum, Mexico showed large gains in human development in the twentieth century, but these were mostly driven by policies in the decades of urbanization and rapid industrialization.

\subsubsection{Convergence}

Studies of convergence of the GDP per capita of Mexican states have found a significant reduction of regional disparities in the period between 1940 and 1990 (see for example Esquivel 1999). Furthermore, Esquivel et al. (2003) in their study of HDI from 1950 to 2000 identified absolute convergence for the HDI and its components. However, previous studies have not used a long-run series since 1895 as we do in this chapter. The literature on convergence identifies "absolute convergence" or "unconditional convergence" when the poorest states or countries in the initial year grow faster during the full period than richest states or countries (on average). Using the HDI instead of GDP, we find absolute convergence for the full period 1895-2010. Figure 3 plots the average growth rates of the HDI between 1895 and 2010 and the $\log$ of the HDI in the initial year (1895). The statistical significance of the negative slope proves the existence of absolute convergence. Similarly, we find absolute convergence in the HDI components: urbanization, health, and education. ${ }^{22}$

\footnotetext{
${ }^{20}$ On health and education see Brachet-Márquez (2010) and Loyo (2010).

${ }^{21}$ GDP per capita fell during the 1980s in Mexico. However, we find that HDI increased during this period, although its growth rate is lower compared to previous periods. It is possible that urbanization (our income proxy) is increasing through informal labor of rural workers tied with economic decline. We thank Luis Bértola for this remark.

${ }^{22}$ In his analysis of the Atlantic economy from 1870 to 1910 George R. Boyer (2007) finds convergence in living standard measures with a stronger trend for the non-income components of well-being.
} 


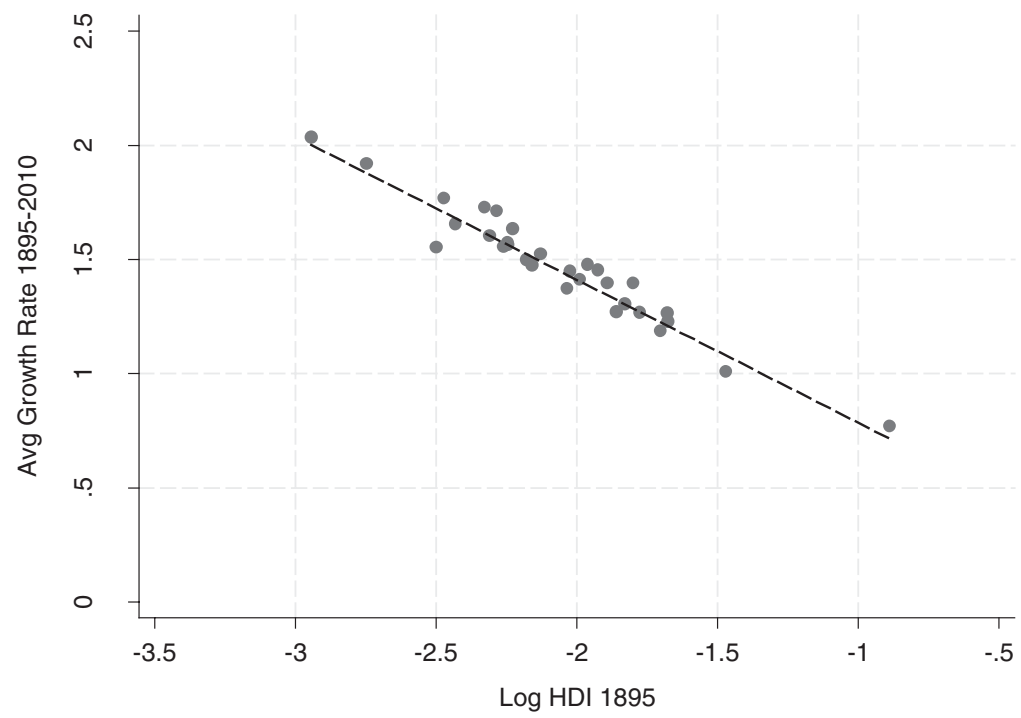

Fig. 3 HDI: absolute convergence. Sources: Historical HDI obtained from results calculated by the authors. Notes: Calculated by the authors. The regression obtained is equal to growth $=0.16-0.62 H D I 1895$, with a $t$-statistic on the coefficient of HDI equal to 26 and $R^{2}$ of 0.96 . Spearman's rank correlation of -0.95

As shown in Fig. 4, the trends in convergence of regional disparities, we find that for the HDI, urbanization and education were relatively stable in the pre-1940 period. In contrast, the health index trend showed an increase between 1920 and 1930, perhaps as a result of successful health campaigns with partial coverage of the national territory. A sharp convergence was common to all indicators from 1940 to 1980. The stability of the coefficient of variation from 1980 to 2010 demonstrates that the gap among Mexican states has stalled in the last 40 years.

\subsubsection{Regional Results}

The HDI is calculated on the regional level as the average of the HDI of the states in the region weighted by their relative population shares. Figure 5 shows the regional HDI for every year of the sample. As in the case of the national data, every region shows improvements in human development over the period of analysis, described by an S-shaped curve. The most significant improvements in human development for every region, excluding Mexico City, occurred between 1950 and 1970, coinciding with the processes of industrialization and urbanization together with the expansion of public education and health services. After 1980 lesser improvements in human development in Mexico's regions are related to the 


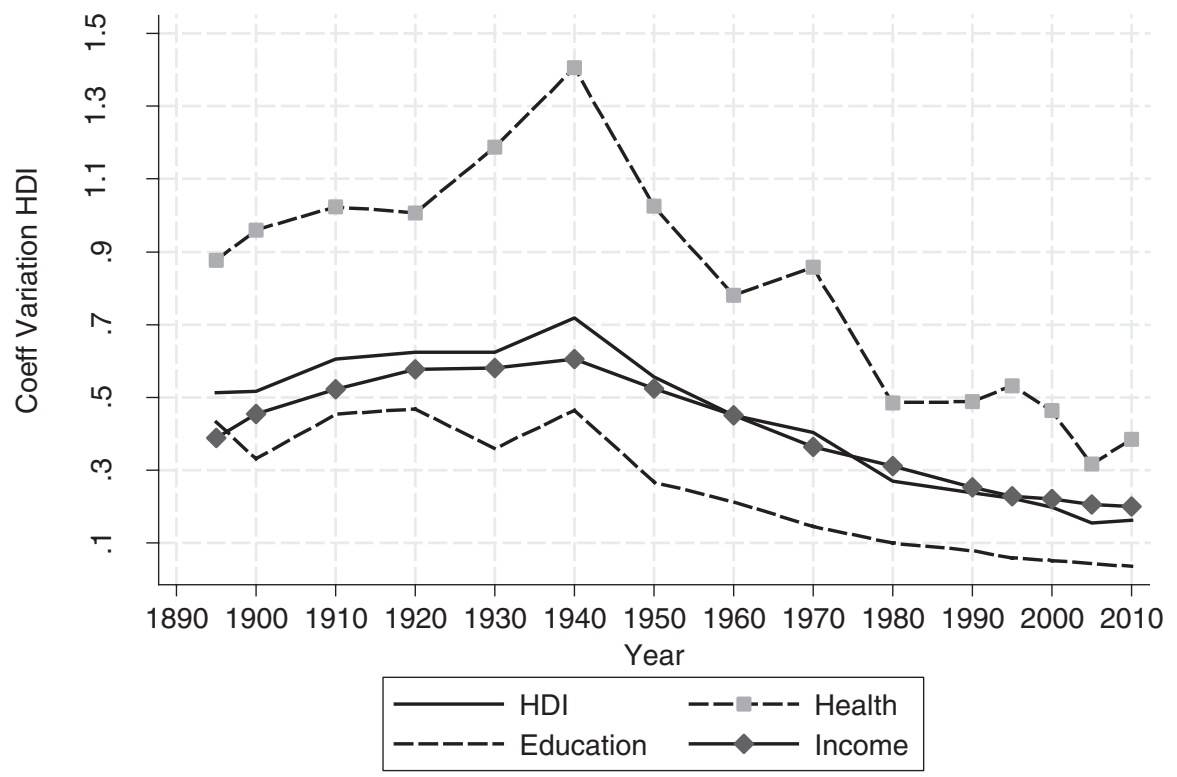

Fig. 4 HDI and components: coefficient of variation. Sources: Historical HDI obtained from results calculated by the authors. Notes: Calculated by the authors using all periods and states

transition to an open economy since the mid-1980s in which macroeconomic adjustments included public expenditure cuts and falling real wages.

Important disparities in human development among states have existed since 1895, as shown in Fig. 5. Mexico City shows the highest standard of living in the sample by a large margin in every year. The northeast and northwest regions consistently show development levels above the national level from 1895, which is comparable to the findings of taller inhabitants of these regions in the analysis of Lopez-Alonso and Velez-Grajales in this volume. In contrast, the center, westcenter, and south-southeast regions have development levels lower than those of the country as a whole. Furthermore, the southern region shows the lowest levels of development for the entire period of study.

One of the most interesting features of Fig. 5 is the comparison between the center and south-southeast regions. Before 1960, the regions' development trends were nearly identical. However, HDI for the center region subsequently improved, catching up with the west-center region and national levels.

The relative positions of the states and the relationship of differences with location are shown in Fig. 6 with the states classified according to their relative development position for the years 1895, 1920, 1940, 1970, 1990, and 2010. Northern states commonly have the highest HDI, while southern and especially southeastern states have the lowest. States in the center and west-center regions have more variable results but in general they are middle ranked. These results suggest a persistence in relative development with a strong spatial distribution. 


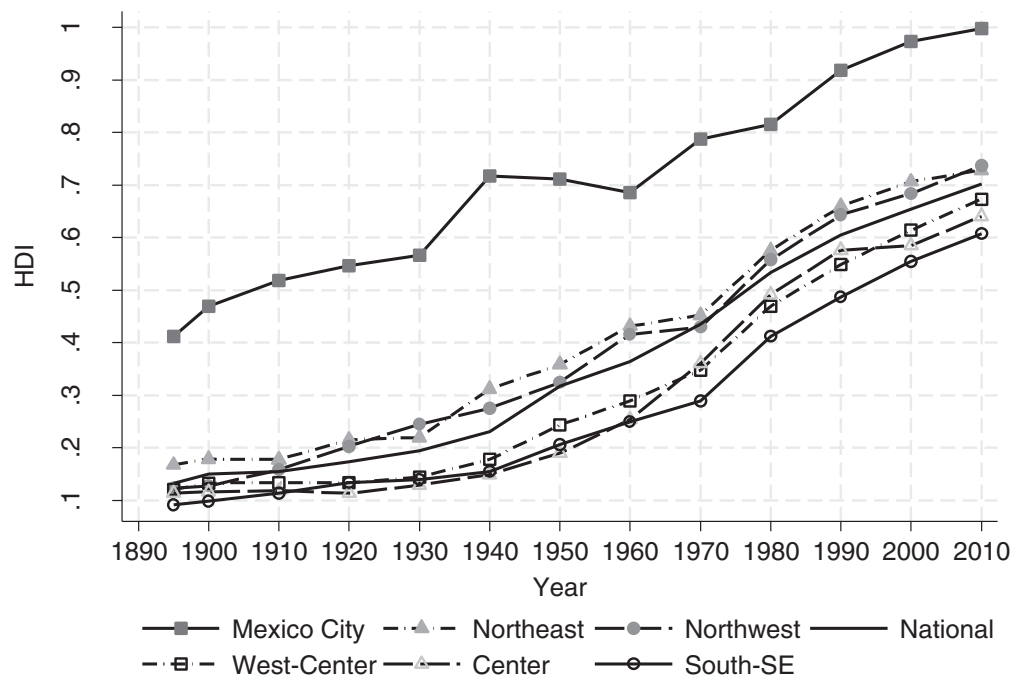

Fig. 5 HDI by region, 1895-2010. Notes: Calculated by the authors, weighted for population of each state and period. Regions are defined as follows: Northeast Coahuila, Chihuahua, Durango, Nuevo León, and Tamaulipas. Northwest Baja California, Baja California Sur, Sinaloa, and Sonora. West-Center Aguascalientes, Colima, Guanajuato, Jalisco, Michoacán, Nayarit, Querétaro, San Luis Potosí, and Zacatecas. Center Hidalgo, Mexico State, Morelos, Puebla, and Tlaxcala. South and Southeast Campeche, Chiapas, Guerrero, Oaxaca, Quintana Roo, Tabasco, Veracruz, and Yucatán

Figures 4 and 5 allow us to understand this pattern. In 1895, northern and Yucatan Peninsula states and Mexico City showed the highest levels of development. During the Porfiriato, foreign trade was key to the economic performance of these states and thus their higher standard of living. This pattern became more evident in the 1920s when northern bordering states rose to the top, along with Mexico City.

The highest dispersion among states is found in 1940. In that year the northern border states and Mexico City still show the highest levels of development, and the center and southeast regions their lowest levels before import substitution industrialization. By 1970, the pattern is not significantly different, although the state of Jalisco has a top position in the standard of living ranking. As dispersion between states is reduced over time, states in the center and the Yucatan peninsula are less uniformly ranked. Guerrero and Oaxaca, however, have ranked in the bottom $25 \%$ since 1895 .

After the debt crisis of 1982 and structural changes to open the economy, regional patterns of development in 1990 remained unaltered. The northern states still ranked highest in human development, but Jalisco, Aguascalientes, and Colima were reaching levels similar to those of the north. Southern states continued in the lowest positions. In 2010, the dispersion had reduced significantly with northern and west-center states experiencing similar levels of development. Although the center has made important improvements, it still includes some of the lowest ranking states in the country. 
A. 1895

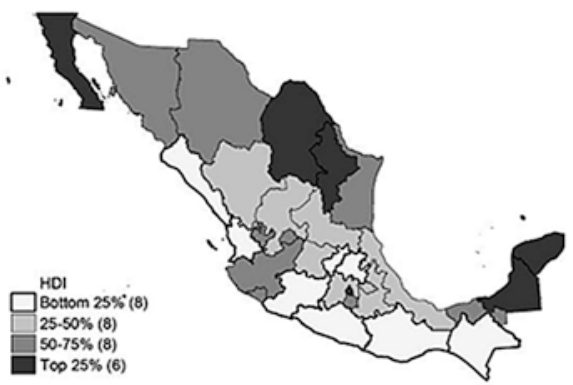

C. 1940

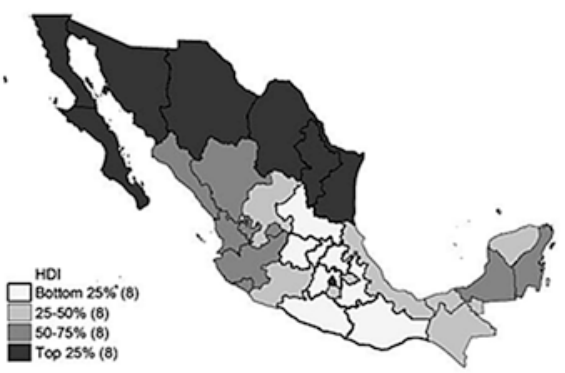

E. 1990

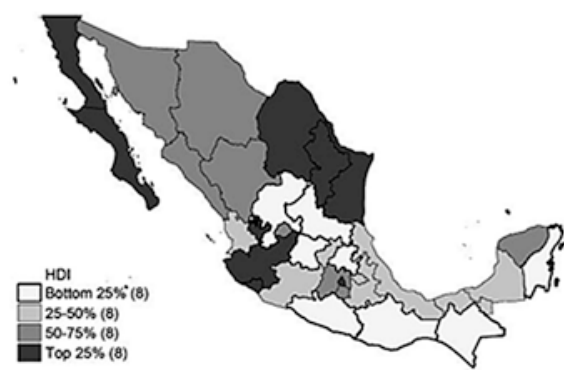

B. 1920

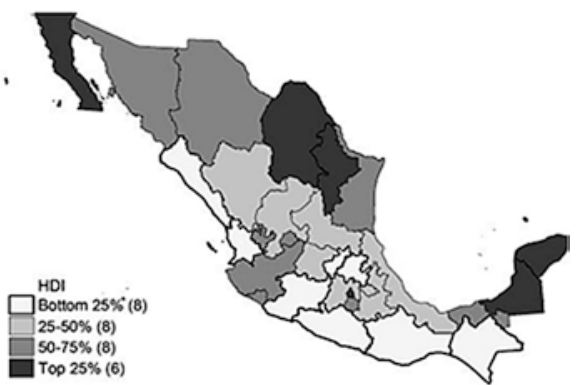

D. 1970

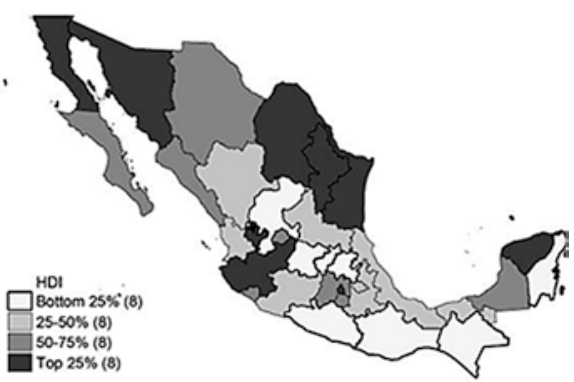

F. 2010

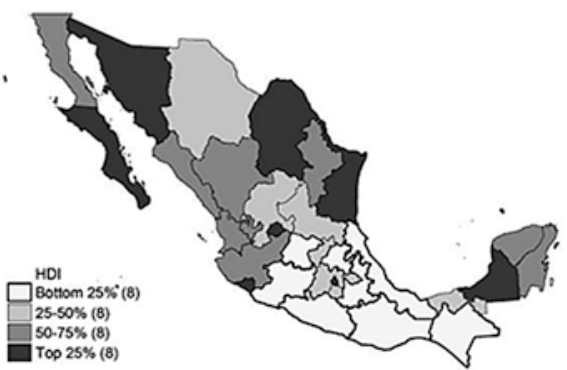

Fig. 6 Development of Mexico, (a) 1895, (b) 1920, (c) 1940, (d) 1970, (e) 1990, (f) 2010. Notes: Calculated by the authors. Mexico has 32 states including the Federal District (Mexico City). Data not available for Baja California Sur and Quintana Roo in 1895 or 1920

Figure 7 shows the scatterplot of the HDI of the states minus their mean for 1895 ( $x$-axis) against the HDI of the states minus their mean for multiple years of the study ( $y$-axis). This plot shows a clear concentration of states in the first and third quadrants, confirming that states with above-average development levels since 1895 remain above average in subsequent periods, and those with below-average levels remain below average - an astonishing persistence in relative development among states. 


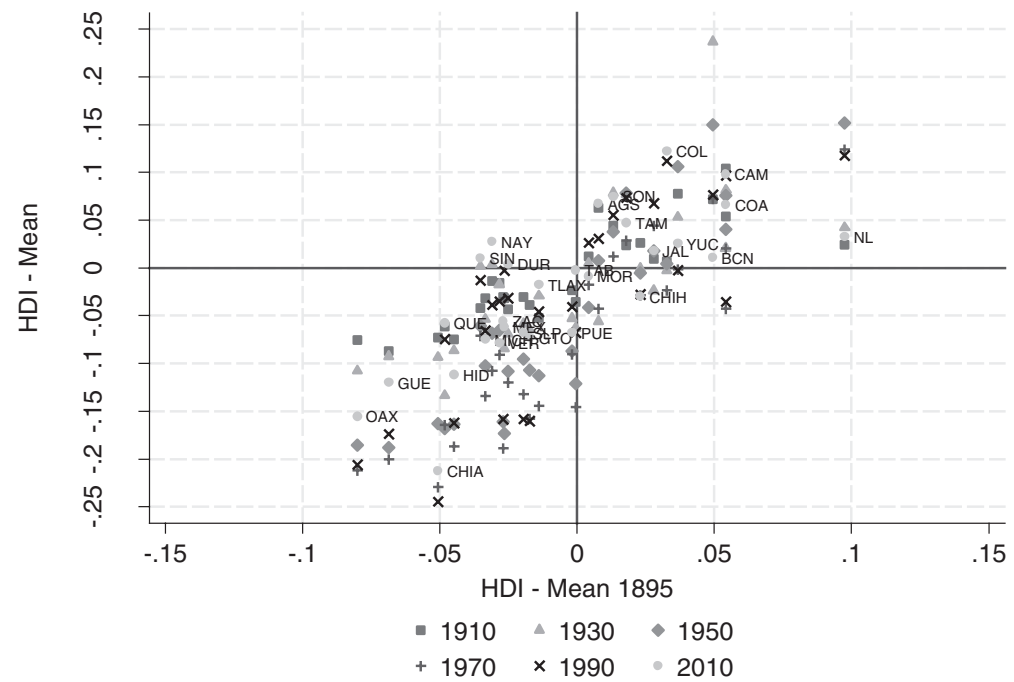

Fig. 7 HDI minus national mean by state, 1895-2010. Notes: Calculated by the authors. $Y$-axis refers to the difference between the HDI of each state and the mean HDI across states for each reference year. Figure does not include Mexico City. States are indicated as follows: AGSAguascalientes, BCN-Baja California, BCS-Baja California Sur, CAM-Campeche, COACoahuila, COL-Colima, CHIA-Chiapas, CHIH-Chihuahua, DUR-Durango, GTO-Guanajuato, GUE-Guerrero, HID-Hidalgo, JAL-Jalisco, MEX-Mexico State, MICH-Michoacán, MORMorelos, NAY-Nayarit, NL-Nuevo León, OAX-Oaxaca, PUE-Puebla, QUE-Querétaro, QROOQuintana Roo, SLP-San Luis Potosí, SIN-Sinaloa, SON-Sonora, TAB-Tabasco, TAM-Tamaulipas, TLAX-Tlaxcala, VER-Veracruz, YUC-Yucatán, ZAC-Zacatecas

Studies by Crafts $(1997,2002)$ and Prados de la Escosura (2010) comparing a sample of countries over time have found that the main determinant for increases in human development is health. Figure 8 shows the decompositions of the sources of growth in the HDI results per decade. ${ }^{23}$

The main determinant of human development until the 1920s is education (measured in literacy and enrollment rates), which contributes approximately $65 \%$. Next in importance from 1895 to 1910 is health (number of physicians), while for the postrevolutionary period it is income (urbanization). The 1930s began a trend of health (number of physicians) as the main contributor to growth in human development. The large expansion in the 1930s can be explained both by the major effort during the presidency of Lázaro Cárdenas to expand health coverage in the rural sector and by the expansion of the welfare state in the 1940s (Brachet-Márquez 2010). Health continued to be the largest contributor to human development after the 1930s (except in the

${ }^{23}$ We follow the decomposition formula as in Prados de la Escosura (2010), p. 18. The formula can be easily derived from taking the total differential to Eq. (1) in natural logarithm:

$$
\text { dlogHDI }=\left(\frac{1}{3}\right) \text { dlogHealth }+\left(\frac{1}{3}\right) \text { dlogEducation }+\left(\frac{1}{3}\right) \text { dlogIncome }
$$




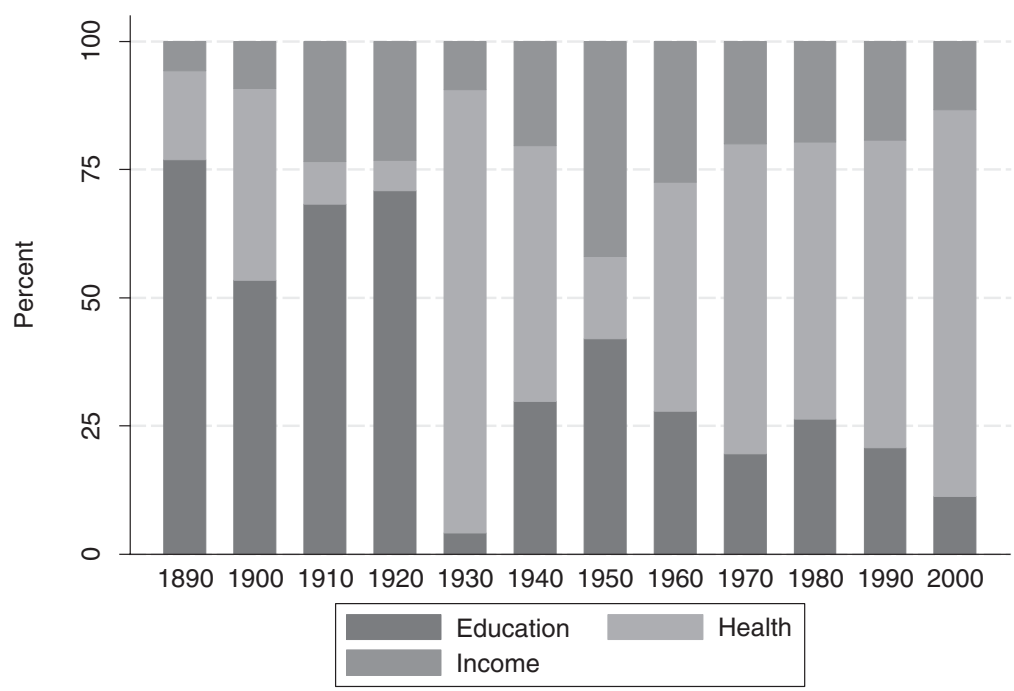

Fig. 8 Decomposition of HDI. Notes: Calculated by the authors. We follow the decomposition formula as in Prados de la Escosura (2010), p. 18. The formula can be easily derived by taking the total differential to Eq. (1) in natural logarithm:

dlogHDI $=\left(\frac{1}{3}\right)$ dlogHealth $+\left(\frac{1}{3}\right)$ dlogEducation $+\left(\frac{1}{3}\right)$ dlogIncome. The contribution of each index is thus calculated as each term in the previous formula over the change in the Q-HDI. The $\mathrm{x}$-axis refers to the contribution of each index for all decades. So we compare the growth rate and the contribution of each index between 1900 and 1910, 1910 and 1920, and so on. The initial year in the 1890 decade is 1895

1950s). On average, health contributes close to $55 \%$ of human development growth for the period 1930-2010. Prados de la Escosura (2010) finds that health contributes $52 \%$ worldwide to human development for the period 1870-2005. Mexico's development is thus relatively close to the international value for the period after 1930 .

\section{Conclusions}

In this chapter, we estimate a measure of long-run development in Mexico by calculating a human development index from 1895 to 2010 at subnational level. This is the longest homogenous series to date that tracks this phenomenon at the national and state levels. We discuss Mexico's well-being in terms of multidimensional characteristics, but we also focus on measurements at the subnational level in order to disentangle regional patterns.

We find that there is a significant increase in human development over the period studied. We identified absolute convergence in the HDI and each of its components with a trend of sharp convergence in the period 1940-1980. Our index begins at 0.13 in 1895 and ends at 0.70 in 2010, representing an acceleration rate of $1.45 \%$. 
For the period from 1895 to 1910, well-being grows at a rapid rate but slows down by the end of the period. For the revolutionary and postrevolutionary period (1910-1930), standards of living increase, although the increase is not homogenous across regions. The largest increases in human development are from 1940 to 1980. From 1950 onward, the gap across states decreases substantially, and after 1980, disparities increased again. Health contributes close to $65 \%$ of total growth before 1930, and $55 \%$ thereafter. These patterns of results are similar to those found by Prados de la Escosura (2010) in an international sample.

We also find a large persistence in regional development patterns across states. Northern states are wealthier than the rest from the beginning of the period, while southern states are the poorest. States surrounding Mexico City were as poor as southern states at the beginning of the century, but they developed more rapidly from 1940 to 1980 . The expansion of the welfare state thus failed to modify the spatial distribution of relative levels of well-being in the country.

In sum, this chapter makes an important contribution to the long-run measurement of well-being in Mexico. Future studies for other countries may take advantage of our methodology to analyze regional patterns, and deepen our understanding of the determinants of change in well-being across regions within countries.

Open Access This chapter is distributed under the terms of the Creative Commons Attribution 4.0 International License (http://creativecommons.org/licenses/by/4.0/), which permits use, duplication, adaptation, distribution and reproduction in any medium or format, as long as you give appropriate credit to the original author(s) and the source, a link is provided to the Creative Commons license and indicate if changes were made.

The images or other third party material in this chapter are included in the work's Creative Commons license, unless indicated otherwise in the credit line; if such material is not included in the work's Creative Commons license and the respective action is not permitted by statutory regulation, users will need to obtain permission from the license holder to duplicate, adapt or reproduce the material.

\section{References}

Acemoglu, D., Johnson, S., \& Robinson, J. A. (2002). Reversal of fortune: Geography and institutions in the making of the modern world income distribution. Quarterly Journal of Economics, 117(4), 1231-1294.

Aguilar Retureta, J. (2015). Regional income distribution in Mexico: New long-term evidence. Working paper E15/323, Universitat Barcelona Economics.

Astorga, P., Berges, A. R., \& Fitzgerald, V. (2005). The standard of living in Latin America during the twentieth century. Economic History Review, 58(4), 765-796.

Bairoch, P. (1975). The economic development of the third world since 1990 (C. Postan, Trans.). Berkeley: University of California Press.

Bairoch, P. (1988). Cities and economic development: From the dawn of history to the present. Chicago: University of Chicago Press.

Bértola, L., et al. (2010). Human development and inequality in the twentieth century: The mercosur countries in a comparative perspective. In R. Salvatore, J. H. Coatsworth, \& A. Challú 
(Eds.), Living standards in Latin American history: Height, welfare, and development, 1750 2000 (pp. 197-232). Cambridge, MA: Harvard University David Rockefeller Center for Latin American Studies.

Bortz, J., \& Águila, M. (2006). Earning a living: A history of real wage studies in twentiethcentury Mexico. Latin American Research Review, 41(2), 112-138.

Boyer, G. R. (2007). The convergence of living standards in the Atlantic economy, 1870-1930. In T. J. Hatton, K. O'Rourke, \& A. M. Taylor (Eds.), The new comparative economic history. Essays in honor of Jeffrey G. Williamson. Cambridge, MA: MIT Press.

Brachet-Márquez, V. (2010). Salud y Seguridad Social, 1917-2008: ¿Quién decide? In J. L. Méndez (Ed.), Los grandes problemas de México (Vol. 13, pp. 343-378). Mexico City: El Colegio de México.

Cali, M., \& Menon, C. (2013). Does urbanization affect rural poverty? Evidence from Indian districts. World Bank Economic Review, 27(2), 171-201.

Campos-Vazquez, R. M., \& Velez, R. (2012). Did population well-being improve during porfirian Mexico? A regional analysis using a quasi-human development index. Journal of Human Development and Capabilities, 13(4), 597-620.

Cárdenas, E. (2003). Cuándo se originó el atraso económico de México. La economía mexicana en el largo siglo XIX, 1780-1920. Madrid: Biblioteca Nueva.

Cárdenas, E. (2010). La economía en el dilatado siglo XX, 1929-2009. In S. K. Ficker (Ed.), Historia económica general de México: de la colonia a nuestros días (pp. 503-548). Mexico City: El Colegio de México.

Challú, A. E., \& Galvarriato, A. G. (2015). Mexico's real wages in the age of the great divergence, 1730-1930. Revista de Historia Económica, 33, 83-122.

Coatsworth, J. H. (1978). Obstacles to economic growth in nineteenth-century Mexico. American Historical Review, 83(1), 80-100.

Colegio de México. (1964). Estadísticas económicas del Porfiriato: Fuerza de trabajo y actividad económica por sectores. Mexico City: El Colegio de México.

Crafts, N. (1997). The human development index and changes in standards of living: Some historical comparisons. European Review of Economic History, 1(3), 299-322.

Crafts, N. (2002). The human development index, 1870-1999: Some revised estimates. European Review of Economic History, 6(3), 395-405.

Esquivel, G. (1999). Convergencia regional en México, 1940-1995. El Trimestre Económico, 66(4), 725-761.

Esquivel, G., López-Calva, L. F., \& Velez, R. (2003). Crecimiento Económico, Desarrollo Humano y Desigualdad Regional en México 1950-2000. Estudios Sobre Desarrollo Humano. PNUD México, 32, 2003-03.

Fierro, C., Tapia, G., \& Rojo, F. (2009). Descentralización educativa en México: Un recuento analítico. OECD working paper. Retrieved from http://www.oecd.org/mexico/44906363.pdf

Frenk, J. L., et al. (1995). Los médicos en México, 1970-1990. Salud Pública de México, 37(1), 19-30.

García-Verdú, R. (2005). El índice de desarrollo humano y su aplicación a las entidades federativas en México. Gaceta de economía, 10(20), 5-29.

Haber, S., Klein, H. S., Maurer, N., \& Middlebrook, K. J. (2008). Mexico since 1980. Cambridge and New York: Cambridge University Press.

Huerta Maldonado, M. (1960). El nivel de vida en México. Revista Mexicana de Sociología, 22(2), 463-527.

INEGI (Instituto Nacional de Estadística y Geografía). (2004). Anuario de estadísticas por entidad federativa 2003. Aguascalientes, Mexico: INEGI.

INEGI (Instituto Nacional de Estadística y Geografía). (2009). Anuario de estadísticas por entidad federativa 2008. Aguascalientes, Mexico: INEGI.

INEGI (Instituto Nacional de Estadística y Geografía). (2010a). Censo General de Población y Vivienda 2010. Aguascalientes, Mexico: INEGI.

INEGI (Instituto Nacional de Estadística y Geografía). (2010b). Estadísticas históricas de México 2009. Aguascalientes, Mexico: INEGI. 
INEGI (Instituto Nacional de Estadística y Geografía). (2011). Anuario de estadísticas por entidad federativa 2010. Aguascalientes, Mexico: INEGI.

Klugman, J., Rodríguez, F., \& Choi, H.-J. (2011). The HDI 2010: New controversies, old critiques. United Nations Development Programme, Human Development Research Paper 2011/01.

Komlos, J. (Ed.). (1994). Statures, living standards and economic development. Chicago: University of Chicago Press.

López-Alonso, M. (2007). Growth with inequality: Living standards in Mexico, 1850-1950. Journal of Latin American Studies, 39(1), 81-105.

López-Alonso, M. (2012). Measuring up: A history of living standards in Mexico, 1850-1950. Palo Alto: Stanford University Press.

Loyo, E. (2010). La educación del pueblo. In Historia Mínima de la Educación en México (coordinated by D. Tanck de Estrada, pp. 154-187). Mexico City: El Colegio de México.

Márquez, G. (2012). Growth and living standards: Evidence from post-revolutionary Mexico. Paper presented at the 16th World Economic History Congress, Stellenbosch, South Africa, 9-13 July 2012.

Márquez, G. (2013). En torno a la depresión del siglo XIX. Las aristas del debate. Unpublished manuscript, El Colegio de México.

Márquez, G., \& Meyer, L. (2010). Del autoritarismo agotado a la democracia frágil, 1985-2010. In Nueva Historia General de México (coordinated by B. García Martínez, pp. 747-792). Mexico City: El Colegio de México.

Mendizábal Othón de, M. (1947). Distribución geográfica de los médicos en la República Mexicana. In Obras Completas (Vol. 6, pp. 529-541). Mexico City: Talleres Gráficos de la Nación.

Minnesota Population Center. (2011). Integrated Public Use Microdata Series (International: Version 6.1) [Machine-readable database]. Minneapolis: University of Minnesota, 2011.

Moomaw, R. L., \& Shatter, A. M. (1996). Urbanization and economic development: A bias toward large cities? Journal of Urban Economics, 40(1), 13-37.

Moreno-Brid, J. C., \& Ros, J. (2009). Development and growth in the Mexican economy. Oxford: Oxford University Press.

Morris, I. (2013). The measure of civilization: How social development decides the fates of nations. Princeton: Princeton University Press.

Myers, C. N. (1971). Proyección de la demanda de médicos en México: 1965-1980. Demografía y Economía, 5(2), 193-227.

Nunn, N., \& Qian, N. (2011). The Potato's contribution to population and urbanization: Evidence from a historical experiment. Quarterly Journal of Economics, 126(2), 593-650.

Permanyer, I. (2013). Using census data to explore the spatial distribution of human development. World Development, 46, 1-13.

Piérard, E. (2009). The effect of physician supply on health status as measured in the NPHS. Working Paper No. 901, Department of Economics, University of Waterloo. Retrieved from http://ideas.repec.org/p/wat/wpaper/0901.html.

PNUD (Programa de las Naciones Unidas para el Desarrollo). (2003). Informe sobre Desarrollo Humano México 2002. Mexico City: Ediciones Mundi-Prensa.

PNUD (Programa de las Naciones Unidas para el Desarrollo). (2012). El índice de desarrollo humano: Cambios metodológicos e información para las entidades federativas. Mexico City: Offset Santiago.

Prados de la Escosura, L. (2010). Improving human development: A long-run view. Journal of Economic Surveys, 24(5), 841-894.

Robst, J., \& Graham, G. (1997). Access to health care and current health status: Do physicians matter? Applied Economic Letters, 4, 45-48.

Robst, J., \& Graham, G. (2004). The relationship between the supply of primary care physicians and measurements of health. Eastern Economic Journal, 30(3), 467-486.

Sánchez Santiró, E. (2009). El desempeño de la economía mexicana tras la independencia, 18211870: nuevas evidencias e interpretaciones. In Latinoamerica y España, 1800-1850. Un crecimiento nada excepcional (coordinated by E. Llopis \& C. Marichal (Eds.), Madrid: Marcial Pons Historia/Instituto Mora 
Secretaría de Economía. (1956). Estadísticas sociales del porfiriato 1877-1910. Mexico City: Talleres Gráficos de la Nación.

Shi, L. (1992). The relationship between primary care and life chances. Journal of Health Care for the Poor and Underserved, 3, 321-335.

Shi, L. (1994). Primary care, specialty care and life chances. International Journal of Health Services, 24(3), 431-458.

Tabellini, G. (2010). Culture and institutions: Economic development in the regions of Europe. Journal of the European Economic Association, 8(4), 677-716.

UNDP (United Nations Development Programme). (1990). Human development report 1990. New York: Oxford University Press.

UNDP (United Nations Development Programme). (2010). Human development report 2010. New York: Palgrave Macmillan.

Vogel, R. L., \& Ackermann, R. J. (1998). Is primary care physician supply correlated with health outcomes? International Journal of Health Services, 28(1), 183-196.

Raymundo M. Campos Vázquez is a research professor at the Center for Economic Studies in El Colegio de México. He holds a Ph.D. in Economics from the University of California, Berkeley, a Master's in Economics from El Colegio de Mexico, and a B.A. in Economics from Tecnológico de Monterrey. His research fields are labor economics, development economics, and econometrics.

Cristóbal Domínguez obtained his Master's in Economics at El Colegio de Mexico and his B.A. in Economics at Tecnológico de Monterrey. His fields of research are economic history and social mobility.

Graciela Márquez holds a Ph.D. in History from Harvard University. Since 2003, she is a research professor at the Center for Historical Studies in El Colegio de Mexico. Her areas of interest are fiscal history of Mexico, history of trade policy, and the reconstruction of the GDP series. Her recent publications include "Claves para la Historia Económica de México" (Fondo de Cultura Económica 2014). 